\title{
Socio-Cultural Attitude Towards Women and Shudras in Ancient Age: A Study of the Vedas and Dharmashastra
}

\author{
Kaushalya
}

\begin{abstract}
Language of the Dalits is one of the most crucial constituent of their identity that gives Dalit literature its distinctiveness. Their language violently disturbs the seemingly natural but superficial orderliness of the social status quo. That is to say, the language of the Dalits goes against the standard language, which is considered to be "pure", "cultured", "classical", and "divine," and which is also the language of the academia. The so-called "decency" is the most suffocating term for the Dalits for it stifles the Dalit voice and self-expression. The Dalit language is definitely decent for Dalits. In the villages, Dalits have been pushed to the outskirts.
\end{abstract}

Index Terms - Varna, caste, Shudra, women, dharmashastra, veda, smṛti.

\section{INTRODUCTION}

Language is arguably the best parameter of gauging the socio-cultural status of any community. A platitude that snatching the language is an easy way to kill a culture. That is why; language has a major role and contribution in all stages of a civilization beyond the time and condition.

Knowledge of Sanskrit language is crucial factor for thorough study of ancient Indian culture because large number of extant ancient texts had composed in Sanskrit. In ancient Indian textual tradition, Sanskrit has many synonyms such as deva-vani, Geervana-vani and Bhaarati. It had used as a medium of literary expression and socio-cultural domination by its bearers and narrators who called themselves 'Aryans'. It use, whether in speech, learning or writing, was prohibited for those $\operatorname{ran}^{1}$ the lowest in the Brahmanical caste hierarchy, i.e., the Shudras, including the untouchable castes. Shudras were completely deprived of the privileged mode of Brahmanical education in Sanskrit in the postVedic period; so, they, unlike the Brahmanas, were unable to construct any scriptural or literary tradition in this that the Dalits were never allowed into the mainstream life of the society is reflected in the different language used by them. The paper proposes to analyze the Vedas and the Dharmashastras in order to understand whether Dalit woman and Shudras were allowed to use Sanskrit and whether the prohibition on their use of Sanskrit induces inequality, and, if so, to understand and analyze the inequality.

For the Shudras, the denial of language for self-articulation was, in effect, the denial of culture as reflected in textual traditions that are used as sources of history by modern scholars. Therefore, in the absence of textual sources composed by the Shudras themselves, a critical study of ancient Sanskrit texts becomes essential for getting

Manuscript received March 2, 2019; revised June 1, 2019.

Kaushalya is with the Department of Sanskrit, Motilal Nehru College, University of Delhi, India (e-mail: panwar.kaushal@gmail.com). knowledge about the socio-cultural conditions of Shudra men and women.

People of various races, castes, classes, religions have been living in the Indian sub-continent since the dawn of civilization. Many researches have been done on cultural, social, economic and political history of India, which became very useful to understand the changing rhyme of developing human society. The governments make policies for deprived sections of the society because of such great research works. However, at the same time, there is still need for more authentic research in order to foreground the obscured aspects of the reality of oppressed communities. The study of Vedas and Dharmashastra (ancient prescriptive texts on social norms and rules) composed by the Brahmanas over a long period has an immense potential to be tapped for understanding ancient India's socio-cultural and religious realities.

There are various semantic meanings of the term 'Dharma' in the Sanskrit intellectual tradition. However, the sociopolitical connotation of dharma is chiefly Varna-dharma, which means duties to be performed in accordance with one's birth in a particular Varna or class. That is why texts called Dharmashastra created, established and continually reinforced the norms governing the birth-based hierarchical structure of ancient Indian society. Profound theorizing of fundamental aspects of society, politics, religion, and individual human life can be seen in these texts. Therefore, we can say that it is impossible to understand and assess ancient India's social, religious, economic and political conditions without the study of Dharmashastra. This essay uses the Dharmashastra to evaluate and understand the societal attitudes towards the Shudras in general and Shudrawomen in particular, as well as their role and contribution in the functioning of socio-cultural organization of ancient India.

\section{SOCIAL CONDITIONS OF SHUDRA IN ANCIENT INDIA}

The welfare of all human beings has been supreme goal of Indian religion and philosophy. Ancient Vedic tradition accepts the entire world as one family and says; "Yatra vishvam bhavatyekaneedam [1] ("where world is like one shelter'). From the social point of view, various communities were adopted in the Vedic society in a gradual fashion, finally leading to the creation of a four-fold hierarchical social order called the varna system in which each varna or class was ascribed a particular hereditary rank and function. Subsequently, a complex caste system with its many Jaati or caste- groups originated from this varna system. Shudras got the lowest position in the varna system. 
As reflected in the famous Purusha-sukta or hymn of creation in the Rigveda, the oldest extant text in the Vedic literature, which describes the Shudra's origin from the feet of the purusha (the primeval man) and that of the other three upper varnas, viz. the Brahmana, the Raajanya or Kshatriya and the Vaishya from his head, arms and thighs respectively:

brāhmaṇo'sya mukhamāsīt bāhū rājanyah kṛtah, uru tadasya yadvaiśyah padbhyām śūdroajāyat. [2]

(Brahmana was his mouth; the Kșatriya was included as his two arms; as to his thigh that is what the Vaisya was; the Shudra originated from his feet.)

One of the earliest Dharmasutras, the Gautama Dharmasutra says: Shudra is the fourth varna and constitute one caste (jati) [3]. No education in any form was prescribed for Shudra; therefore, this community was excluded from the upanayana sacrament, an important Brahmanical rite of initiation into education, marked by the wearing of the sacred thread. Only the first three varnas had allowed performing the upanayana rite that entitled them to the status of dvija or 'twice-born man' (the biological birth, and the ritual birth). Serving the upper three varnas were upheld as the supreme duty and virtue for the Shudra. According to Aapastamba Dharmasutra, duty of the Shudra is to nurse the three upper varnas [4]. Hence, a Shudra's livelihood and virtue depended on serving the upper varnas. A Shudra could gradually receive the fruits of offering his/her best service to the upper varnas. Even a Shudra's service was ranked hierarchically based on the varna of the one who was to be served. Thus, serving a Kshatriya had considered better than serving a Vaishya, and serving a Brahmana even better than serving a Kshatriya [5]. The Shatapatha Brahmana, a later Vedic text, says that melted glass should be poured into the ear of a Shudra if he found listening the Vedas, his tongue be cut out if he/she found to recite the Vedas and his heart be wrecked if he/she found to memorize the Vedas, keeping them in heart [6]. A Shudra had excluded from the privileged Brahmanical socio-cultural world. He had no right to study the Vedas, undergo the upanayana rite and participate in any ritual or sacrifice.

It is remarkable that the taxes, while elaborating the birthbased duties and privileges of the men of the four varnas, are silent on the status of women. Women, generally undifferentiated by varna, were ascribed a range of roles from serving the husband to performing domestic and agricultural work, but virtually negligible ritual role. Indeed, the very creation of women is missing from the Rigvedic creation hymn that only describes the birth of men of different varnas from the limbs of one primeval or divine man. In other words, why there is no feminine counterpart "Stree-Sukta" as it were to the Purusha-sukta in the Vedic texts? Why women as an undifferentiated category, like the Shudra men, were not permitted to undergo the initiation rite of upanayana, but unlike the Shudra men, ascribed no varna-specific roles or duties and entitlements? Such crucial questions arise from the feminist point of view. The analysis of Dharmashastra provides the answer. These texts not only legitimized the divine origin of the varna system, but also the patriarchal domination on all women whose specific varna identity or status thus became irrelevant to their general subordination to men. The seeds of gender and caste hierarchies were sown at the time, but their interlinkages are not easily visible. The Manusmriti, for instance, says:

"For women, tradition tells us, the marriage ceremony equals the rite of Vedic sacrament [i.e., the upanayana]; serving the husband equals living with the teacher; and care of the house equals [the daily] tending of the sacred." [7]

Suvira Jaiswal emphasizes the need for a re-analysis of the Vedic texts from a social point of view in order to understand the attitudes towards women. For instance, emphasizing the signifiance upanayana as ritual for 'rebirth' for the men of upper varnas implies privileging the ritual birth controlled by men over the biological birth where men and women have complementary roles. The myth of divine provenance of mortal men from a primeval man, by excluding women, degrades women in relation to men. Women of all varnas were socially marginalized and discriminated just like the Shudras. The Shudras and women had no rights or entitlements apart from duties. Women were slaves inside the household while Shudra were by birth slave both inside and outside the household. Thus, the household conceptualized in the Dharmashastra was a Brahmanical patriarchal structure that subordinated both women and the Shudras to the men of upper varnas. While women were shackled by the norms of Brahmanical patriarchy, the Shudras were shackled by the norms of the Brahmanical caste system. The condition of the Shudras and women were the same except that a woman's life was regulated within her particular varna by her male relatives (father, brother, husband, son), and the Shudra's life by unrelated men of the upper varnas. The upper caste women were expected to follow and serve their upper-caste male masters, and the Shudras became untouchable for uppercaste women just as they were for the upper-caste men. Even the Shudra men lorded over their womenfolk just as their upper-caste masters did over their womenfolk. The Shudra woman thus was burdened by double slavery or servitude, one to her upper-caste master and mistress, and the other to her own men folk. In other words, slavery or servitude was double-layered: the first stratum was the subjugation of Shudra varna as a whole irrespective of gender, and the second was the subjugation of Shudra women within household to her kinsmen. Thus, caste and gender hierarchies enforced simultaneously.

\section{Cultural Perspective ABout Shudra IN ANCIENT INDIA}

The gradual development of a reformist discourse that seeks to create a positive consciousness about human equality and dignity has underpinned the continuous efforts over the last two centuries to give a respectful place to women and secure their human rights in the modern Indian democratic society. Many socio-religious reform movements and discourses have been helpful in improving the condition of women and the societal attitudes towards them, but the powerful reactionary force of Brahmanical dominance is still very much in place. This reactionary force that has sought to keep the society divided along caste lines has been endorsed by Brahmanical texts such as the Manusmriti: 'The name of a Brahmana should symbolize his purity, a Kshatriya's name should indicate strength, a Vaishya's name should be symbolic of his wealth and the name of a Shudra 
should be degrading and repulsive' [8]. Paarasara, a Brahmana law-giver, has expressed his sorrow and worry about the characteristics of Kaliyuga by stating that goodness is now defeated by evil manners and truth vanquished by untruth, thieves have become victorious over the kings and the women over the men, the Agnihotra sacrifice and the prayers of the seers have stopped, (unmarried) girls are undergoing abortion and all these (bad) habits are happening because of the appearance of Kaliyuga, the age of sin [9]. An analogy had used in the Atharvaveda and Rigveda [10] to imply that only the women who are fully dedicated to and surrender before their husbands had the respectable place in the society and they are considered women of character. The Atharvaveda calls such women supatnee (good wife). A marriage hymn from the Atharvaveda instructs the woman to be 'anuvarttinee' (follower) of her husband because she dedicates her life permanently for following her husband from her marriage to her death. Sayana's commentary on the Rigveda has a fable about a king who lost his virility by a divine curse and his wife who restored his masculinity by her own austerity. [11] The Manusmriti and Yagyavalkyasmriti prescribe marriage with upper-caste for lower-caste women as a way of attaining social superiority and respectability. The Manusmriti says; "Akshamala was born in a lower caste but got a respectable place in the society by her marriage with the seer Vashishtha and Sharangee attained superiority through her marriage with the seer Mandapala [12]. Similarily, the Yagyavalkyasmriti says; Different lower-caste women got respectable position through marriage with men who had respectability in the society [13]. Both the afore-cited verses suggest that the emancipation of a woman is only possible after her marriage with a respectable, i.e., upper-caste man. The word 'Neechayoni' denotes the social status of woman born in a low caste. They further imply that a woman by herself does not qualify for respect or honor, but can only attain it through marriage with an upper-caste man who is inherently respectable or honorable. A wife has to act as per the guidance of her husband and she is not independent in taking decisions. Her dreams, desires and her very existence are just valueless. The Brahmanical social order considered a woman respectable only insofar as she remained in life-long servitude to her husband. If she deviated from this norm of respectability, she was branded characterless. 'Patitaa' is a term used for those women who lost their respect in society by acting against the wishes of their husbands. A prostitute is called 'Veshya' but there is no such word for promiscuous men. Thus, it can be easily seen through such pejorative terms the patriarchal society created an oppressive environment for women who did not or did not wish to conform to its norms. On the one hand, domesticated, dutiful and subservient women were honored for being 'good' mothers and wives, they in reality lived like a slave. On the other hand, descriptors such as Patitaa or Veshyaa were readily attached to women who even thought of breaching the patriarchal norms. By making such discriminatory and restrictive norms, bestowing honor for conformity and prescribing censure and punishment for non-conformity, the Dharmashastras played a major and decisive role in consolidating a patriarchal caste society. Even for men who violated such norms, the penance and atonement were strict. Describing the food habit rules, the lawmakers advise that a man should be avoided if he is living under the guidance of his wife:

\section{Avīśastrī svargakārastrīṇi tagramayāṇinām, śastravikrayikarmāratantuvāyaśrvavṛtinām. [14]}

The food of Vaishya is inedible and Yagyavalkya prohibits a man from eating with wife in the same cupule: A man should not eat in the same plate with a woman. A woman, while eating, sneezing, yawning and randomly sitting, should not be seen by a man [15]. Man should not eat by standing in front of wife in one cloth. Yagyavalkya prescribes death penalty for a man who committed rape of a woman of higher caste, but a heavy monetary penalty if he raped a woman of a lower caste woman. The Naradasmriti recommends death penalty for a woman who murdered her husband, underwent abortion or was impregnated by a lower-caste man. [16] If a man had sexual intercourse with his female servant, child's babysitter or wife of servant; he is punishable with penalty of 50 panas. Dharmashastra is a representative name of various genres of Sanskrit texts containing Brahmanical rules of conduct, viz. Sutra, Smriti, Arthashastra, epics, Puranas, their commentaries and essays. These are the essential components of the Indian intellectual tradition. All these genres have a distinctive approach towards women. They contain a variety of terms for addressing women, which are fully based on gender discrimination. Some examples are remarkable: ojasvati, sahasraveeryaa, saheeyasi (courageous woman); maneesha; (subjugated woman), Raagyin (woman with a radiant character), Sabhasadaa (woman fit for siting in the sabhaa, i.e., court or assembly), Ashadha (undefeated woman), Yajniya (woman fit to perform sacrifice) [17].

The Shudra as a category and Shudra women therein, have passed through different situations of discrimination, exclusion and marginalization from the Vedic period onwards. Many Dharmashastras glorified the monarchy and birth-based caste system and at the same time, suppressed the Shudras by way of prescribing discriminatory rules. Study of major Dharmashastras can be surmised that condition of Shudras in general and Shudra women in particular would have been the same. The law-givers did not draw distinction between the Shudra men and women in their rules and almost completely excluded women from their entire discourse on varna, though Shudra women would have been more oppressed than men because of their gender, aside from caste. Though the Brahmana lawgivers only theoretically structured the varna system and codified the caste rules in a prescriptive fashion, but the fact they assigned to themselves the pre-eminent position, and that they were perceived as such and patronized by the other upper castes actually put them at the apex of the caste pyramid. The superiority or inferiority of one varna was relative, i.e., it was based on the position of another varna. Brahmanas were already superior because they were the creator of this system. For maintaining their position, they created the theory of religious superiority and purity. Elaborate dietary rules, restrictions on interdining, inter-marriage, ideas of purity and impurity/pollution and the practice of untouchability were the result of this Brahmanical discourse. This dominion war affected not only the Shudra and Shudra women but also produced another community, which was totally untouchable and excluded 
from the society but were settled at the bottom of the system. This community was later known by the term 'Antyaja' [18]. The Antyaja was the fifth position in the Hindu society. This community was called 'Chandala,' which was completely excluded from the mainstream caste society. Dining and marrying with them was banned for other caste groups [19].

\section{CONCLUSION}

Countless social movements and struggles have striven to give dignity and respect to all human beings. They have helped them establish their respectable identities and highlighted their role and contribution. The society has changed a lot since ancient times; social values and customs, too, have changed as a result. Now, we cannot treat any human being by his/her birth, caste, colour, gender, etc., just as the Dharmashastras want us to. The deprived communities discussed in this essay were denied a respectable or honorable position throughout history. They were just wage-less slaves for dvija communities. This slavery was eternal, immutable and was begun from their very birth in this world. They, unlike the African slaves in North America, had no opportunity to buy back their freedom. They had no rights to property, participation in rituals, language (Sanskrit), even their own bodies. But modern politico-intellectual discourses and movements brought about historical changes in their position. Contribution and work of a man were decided by the religion and philosophy in ancient India. These philosophies were dependent on the God, faith, ideas of sin and virtue, etc., but these are not the eternal or universal rules. Actually, these customs were created by selfish communities and they glorified it as the divinely created and permanent system. Dominant communities had secured their superiority over the people, but this anti-humanistic approach created the great hierarchy in ancient India. Even modern India is still suffering from the disease of untouchability and birth-based caste discrimination. In particular, the Shudra women are passing through very bad condition. Rapes, honor-killings, gender and opportunity based discrimination are still breaking the pace of social progress. All these problems are located in this research and we can say that these are rooted in our ancient texts and we can find the path of humanity from our past also.

\section{REFERENCES}

[1] Rigveda (Sayanabhaashyasahita): Ed. F. Maxmular, Second Edition, 1890-1892.

[2] Yajurveda: Trans. R.T.H. Graphite, Banarasa, Vol. 1-2, 1816.

[3] Gautamadharmasutrani: Trans. Pandey, Umeshchandra, Chowkhamba Sanskrit Series, Varanasi, 1966.

[4] Arthashastra: Vachaspati Gairola, Vidyabhavana, Varanasi, 1952.

[5] Vashishtha Dharmasutra: Caukhamba Sanskrit Series, Puna, 1930.

[6] Aapastambadharmasutram: Ed. Pandey, Umeshchandra. Caukhamba Sanskrit Series Office, Varanasi, 1969.

[7] Gautamadharmasutrani (with Mitaksharavritti): Ed.

[8] Pandeya Umeshchandra, Caukhamba Sanskrit Series office, Varanasi, 1969.

[9] Baudhayanadharmasutram: Ed. Pandeya Umeshchandra, Caukhamba Sanskrit Series Office Varanasi, 1969.

[10] Aapastambadharmasutram: Ed Dr. Pandeya Umeshchandra, Caukhamba Sanskrit Series Office, Varanasi, Saṃskaraṇa 1969.

[11] Baudhayanadharmasutram: Ed. Dr. Kumar Narendra, Vidyanidhi Publication, Delhi, 1999.

[12] Vaidika 'Manusmriti': Harideva Arya, Madhura Publication, Delhi, 1996.

[13] Smritisandarbha: Gurumandala Granthamala

[14] Manusmriti: Ed. Janardana Jha, Siddhartha Books, Delhi, 2011.

[15] Bharadvajasmriti: Kolkata, 1939.

[16] Yagyavalkyasmriti: Trivendrama Sanskrit Sanskarana,1922.

[17] Yagyavalkyasmriti: Caukhamba Sanskrit Pratishthana, Delhi, First Ed., 2002.

[18] Vishnusmriti, Adyar Library and Śodha Kendra, 1996.

[19] Gautamadharmasutrani: Trans. Pandey, Umeshchandra, Chowkhamba Sanskrit Series, Varanasi, 1966.

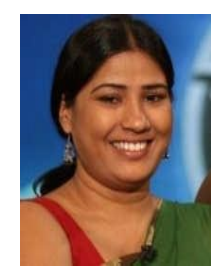

Kaushlaya is assistant professor with the Department of Sanskrit, Motilal Nehru College, University of Delhi. She has successfully worked for her M. Phil. degree in Sanskrit from 2002 to 2003, the Title of her Dissertation was 'Samhitaaon mein Shudra' from Maharshi Dayanand University, Rohatak, Haryana, India. She earned her Ph.D. in Sanskrit language, 2009 from Jawaharlal Nehru University, New Delhi. She has also acted as a Cultural Ambassador of India and given lectures on India's incredible cultural diversity. Her areas of specialized study and interest include Dharmashastras and the position of Shudras (particularly Shudra woman) in ancient history, Varna-System, Casteism, Language of Śhudra and woman, Social movements in India. She has been invited as an outer member of Affirmative Action Tata Power institute, New Delhi, Governing Body member of Sanskrit Sahitya Academy New Delhi. She has been awarded with "Ambedkar In India Samman 2012" in the contribution of Writing, Journalism, inhalation of Untouchables" given by Ambedkar in India magazine published by Kushinagar, U.P., National Commission for woman, Govt. of India presented an award as an "OUTSTANDING WOMAN" on the occasion of International Women's Day March 2013. She has been invited by national media of India as well as abroad. 